\title{
The Measurement of Intrapuff Nicotine Yield*
}

by

\author{
Evon L. Crooks and Dwo Lynm
}

\author{
R. J. Reynolds Tobacco Company, \\ Research and Development, \\ Bowman Gray Technical Center, \\ Winston-Salem, North Carolina 27102, U.S.A.
}

\section{SUMMARY}

Time-resolved measurements of intrapuff nicotine yield in mainstream smoke have been performed with a specially designed intrapuff smoking apparatus (IPSA). The IPSA-filter traversing mechanism collects mainstream particles on a rectangular filter pad which moves at a constant velocity perpendicular to the direction of smoke flow at the mouthend of the cigarette. Filter pads were assayed by two analytical techniques. Standard gas chromatographic (GC) methodology was used to quantify nicotine mass in five equal time segments per puff. A second method, using a Berthold TLC-Linear Analyzer, measured total radioactivity across the pad for samples from $\left[2^{\prime}-{ }^{14} \mathrm{C}\right]$-nicotine labelled cigarettes.

Intrapuff nicotine concentrations were determined from measured puff flow-rate profiles and the collected masses of nicotine on the filters. GC nicotine concentration measurements correlated well with total activity from the scanner measurements. Studies carried out with filtered full-flavor cigarettes revealed that nicotine concentrations in the smoke vary significantly during a puff.

This work provides a new technique for studying timeresolved yields of mainstream smoke components. It may potentially be used to elucidate mechanisms controlling the yield of nicotine and other mainstream smoke components.

\section{RESUME}

On a mesuré en fonction du temps, au cours d'une même bouffée et au moyen d'un appareillage de fumage spécialement conçu à cet effet (IPSA), la quantité de nicotine

\footnotetext{
* Received: 14th August 1990 -

accepted: 26th September 1991
}

contenue dans la fumée du courant principal. Le mécanisme de traversée du filtre IPSA est tel quie les particules $\mathrm{du}$ courant principal sont recueillies sur un tampon filtre rectangulaire qui se déplace à vitesse constante perpendiculairement à la direction du flux de fumée à l'extrémité proximale de la cigarette. Les tampons filtres ont été mis en œuvre avec deux méthodes analytiques. La chromatographie en phase gazeuse standard (GC) a été utilisée pour déterminer la masse de nicotine correspondant à cinq segments de durée égale par bouffée. Une seconde méthode utilisant un analyseur linéaire TLC de Berthold a permis de mesurer la radioactivité totale à travers le tampon pour des échantillons de cigarettes marquées $\left(2^{\prime}{ }^{14}{ }^{14} \mathrm{C}\right.$-nicotine).

Les concentrations de nicotine pendant chaque bouffée ont été déterminées à partir des profils mesurés et des masses de nicotine recueillies sur les filtres. Les mesures de la concentration de la nicotine par chromatographie présentent une bonne corrélation avec l'activité totale mesurée par le scanner. Les études réalisées avec des cigarettes «full flavor» à filtre révèlent que les concentrations de nicotine dans la fumée varient de manière significative au cours d'une même bouffée.

Ce travail fournit une nouvelle technique pour étudier en fonction du temps le rendement des composants de la fumée du courant principal. Ce procédé est susceptible d'être utilisé pour élucider les mécanismes régissant la quantité de nicotine et d'autres substances se trouvant dans le courant principal.

\section{ZUSAMMENFASSUNG}

Mit. Hilfe eines speziell hierfür entwickelten Meßgeräts (IPSA, Intrapuff Smoking Apparatus) wurde die Nikotinkonzentration im Hauptstromrauch während eines Zuges in Abhängigkeit von der Zeit gemessen. Der IPSA- 
Filter-Traversing-Mechanismus sammelt Partikelbestandteile des Hauptstromrauchs auf einem rechteckigen Filter, der sich mit gleichbleibender Geschwindigkeit senkrecht zum Rauchstrom am Mundende der Cigarette bewegt. Die Filter wurden mittels zweier analytischer Verfahren untersucht. Hierfür wurde die Dauer eines Zuges in fünf gleiche Zeitabschnitte unterteilt und mit konventioneller Gaschromatographie (GC) die Nikotinkonzentration während dieser gleich langen Zeiteinheiten bestimmt. Mit einer zweiten Methode wurde mittels Berthold-TLC-Linear-Analyzer die gesamte Radioaktivität quer über den Filter an Proben mit $\left[2{ }^{\prime}{ }^{14} \mathrm{C}-\right]$ markiertem Nikotin untersucht.

Die Nikotinkonzentrationen während eines Zuges wurden aus der gemessenen Zuggeschwindigkeit und dem auf den Filtern gesammelten Nikotin errechnet. Die gaschromatographisch gemessenen Nikotinkonzentrationen korrelierten dabei gut mit der Gesamtaktivität, die mittels Scanner nach radioaktiver Markierung gemessen wurde. Untersuchungen mit regulären ,full-flavor ${ }^{c}$ Cigaretten zeigten, daß die gemessenen Nikotinkonzentrationen im Tabakrauch während eines Zuges stark variieren.

Diese Arbeit beschreibt eine neue Technik zur Untersuchung zeitabhängiger Konzentrationen von Inhaltsstoffen des Hauptstromrauchs. Möglicherweise kann das beschriebene Verfahren dazu beitragen zu klären, welche Zusammenhänge den Gehalt an Nikotin und anderen Inhaltsstoffen des Hauptstromrauchs beeinflussen.

\section{INTRODUCTION}

It has become increasingly important to better understand the mechanisms by which smoke components (especially nicotine) are yielded in mainstream smoke. To this end, instrumentation was developed to provide a means to time-resolve and quantify the concentration of mainstream smoke components during individual puffs. Central to the function of IPSA is a means of measuring puff flow-rate profiles accurately. The method for measuring puff profiles is a modification of the procedure developed by Reynolds (1).

The absence of these types of measurements in the literature is testimony to their difficulty. CESCHINI (3) reported the evolution of gas phase and total particulate matter (TPM) of cigarette smoke in a single puff. The data indicate that the concentration of some individual smoke components is significantly higher at the end of the puff, whereas the TPM was approximately uniform. However, those experiments may be inherently erroneous as partial puffs were used to arrive at conclusions regarding a continuous intrapuff. By contrast, the results presented here were obtained directly from the continuous intrapuff measurements.

In this study, the influence of flow on the delivery of mainstream nicotine during a two-second puff was demonstrated.

\section{INSTRUMENTATION}

\section{A. Intrapuff Smoking Apparatus}

A system was developed to capture smoke particulate matter in real-time during an individual puff. The apparatus configuration was such that near-zero dead volume existed between smoke exiting the cigarette and the collecting filter pad. This was an important criterion for reducing any loss in smoke particulate matter. Figure 1 is a schematic of the IPSA, illustrating its five interacting components. A $100-\mathrm{cm}^{3}$ piston-type-smoking machine (Filamatic; National Instrument Company; Baltimore, MD, U.S.A.) provides the vacuum necessary for puffing. The timer controls the puffing frequency and interfaces with the computer for puff initiation. A filter pad mounted on a translational stage collects smoke particulate matter as it moves past the mouthend of the cigarette during the puff, thus time-segregating the collected TPM. The pad is adjusted to travel a distance of $10 \mathrm{~cm}$ at a velocity of $5 \mathrm{~cm} / \mathrm{sec}$. A positive-pressure smoking machine allows the measurement of flowrate and calibration of differential pressure transducers (Model DP15-26; Validyne Engineering Corporation; Northridge, CA, U.S.A.). A Reynolds-type (1) flow sensor was inserted immediately between the butt-end of the cigarette and the filter pad to measure puff volume. The flow sensor is part of the flow-measuring apparatus, which consists of three differential pressure transducers attached to a Validyne MC1 demodulator (Model MC1-3; Validyne Engineering Corporation; Northridge, CA, U.S.A.) for signal amplification and demodulation. An IBM AT computer (IBM Model AT Computer; Armonk, NY, U.S.A.) with AsYsTANT+ software (AsYsTANT+ Version 1.04; Asystant Software Technologies; Rochester, NY, U.S.A.) was used for data acquisition.

\section{Figure 1.}

Measurement of time-resolved yields and puff profiles.

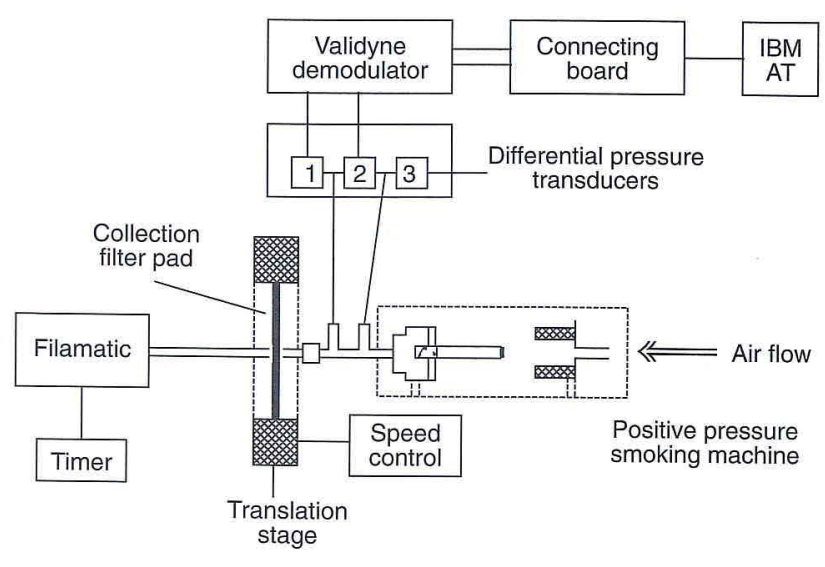

\section{B. Flow Sensor}

Figure 2 illustrates the die-cast low density polyethylene flow probe employed in these experiments. This sensor is 
Figure 2.

Flow sensor.

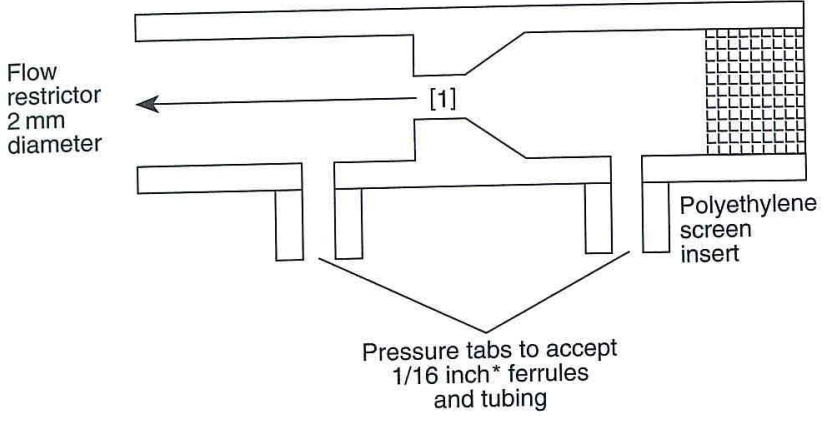

$32 \mathrm{~mm}$ in length, $8 \mathrm{~mm}$ o.d. and $6 \mathrm{~mm}$ i.d. The pressure taps are $8 \mathrm{~mm}$ in length with Swagelok threads. A flow restrictor [1] is located in the center of the tube with a 2-mm diameter hole. At the cigarette end of the sensor the restrictor is cone-shaped as indicated. As air flows through the sensor, a pressure differential across the probe is generated. The differential produced is proportional to flowrate through the sensor.

A differential pressure transducer system was set up such that one transducer measures pressure differential across the taps of the flow sensor, while a second measures absolute pressure. A third transducer was required to balance signals and reduce oscillation between the sensors. Readings from the third transducer were not used in measurement.

\section{Calibration of Flow System}

The three transducers (Figure 3) were Validyne DP15 models equipped with +/- 1.0 PSID measurement diaphragms. The transducers' pneumatic connections were made with $1 / 16$ inch* o.d. tubings of either plastic or stainless steel with Swagelok connectors. The transducers' wiring was routed to a Validyne MC1 demodulator with three independent channels consisting of a CD19A carrier demodulator with a common PS238 power supply (Demodulator Power Supply Model PS 238; Validyne

Figure 3.

Flow sensor calibration.

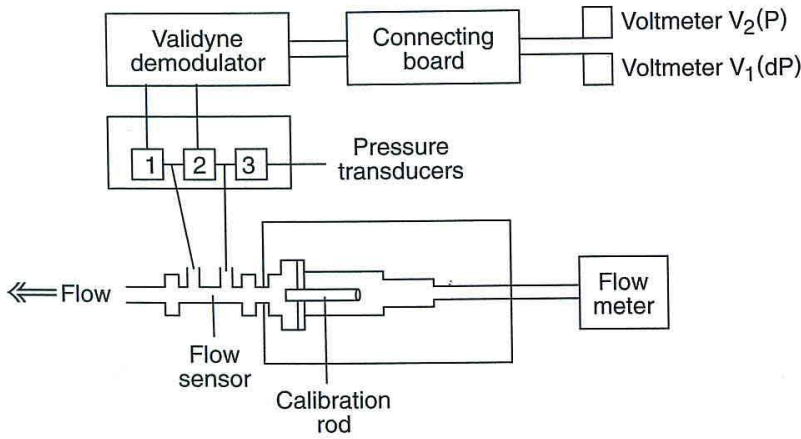

$\because 1$ inch $=2.54 \times 10^{-2} \mathrm{~m}=25.4 \mathrm{~mm}$
Engineering Corporation; Northridge, CA, U.S.A.). The carrier modules provided independent adjustment of zero level and signal amplification. The transducer demodulator outputs were connected directly to the A/D board (Model Data Translation 2801; Data Translation; Marlboro, MA, U.S.A.) via a connecting board (Model Data Translation 707).

A calibration apparatus, which permitted the generation of varied flow rates by vacuum through a critical orifice, was assembled as shown in Figure 4. An empiricallydetermined equation related the differential pressure across the sensor taps $d P$ and mouthend pressure $P$ to flow rate $F$. The form of the equation is:

$F=A \cdot(d P)^{B} \cdot(P)^{C}$,

or

$\ln (F)=\ln (A)+B \cdot \ln (d P)+C \cdot \ln (P)$

where $A, B$, and $C$ are constants.

Voltage signals generated by the pressure transducers are directly proportional to the pressure variables in Equation [2]. Therefore, a second set of relationships is required to convert the voltages into the necessary pressure data:

$d P=A+B \cdot V 1$

and

$P=B P-A^{\prime \prime}-B^{\prime \prime} \cdot V 2$,

where

$B P$

$V 1$ and $V 2$

$A, A^{\prime \prime}$, and $B, B^{\prime \prime}$

is barometric pressure, are measured voltages, are constants for a given transducer. Since transducers measure differential pressure only, Equation [4] must include the barometric pressure to obtain the absolute pressure in Equation [2].

The system illustrated in Figure 4 was used to determine the transducer calibration Equations [3] and [4]. First, transducer 2 was connected to the apparatus and a known vacuum was imposed. Voltage signals were obtained from transducers 1 and 2 under vacuum. The coefficients in Equations [3] and [4] were then determined by linear regression analysis. The nominal vacuum produced was approximately $200-\mathrm{mm} \mathrm{H}_{2} \mathrm{O}$. All transducer arrays were adjusted so that ambient pressure produced $0.00+/-0.02$ volts; a $200-\mathrm{mm} \mathrm{H}_{2} \mathrm{O}$ house vacuum produced a $+2.0-$ volt output from transducer $2, V 2$, and a +10.0 -volt output from transducer $1, V 1$. This procedure was followed for each experiment.

The flow sensor calibration apparatus is shown in Figure 3. After the transducers were calibrated, a flow sensor was 
Figure 4.

Calibration of differential pressure transducers.

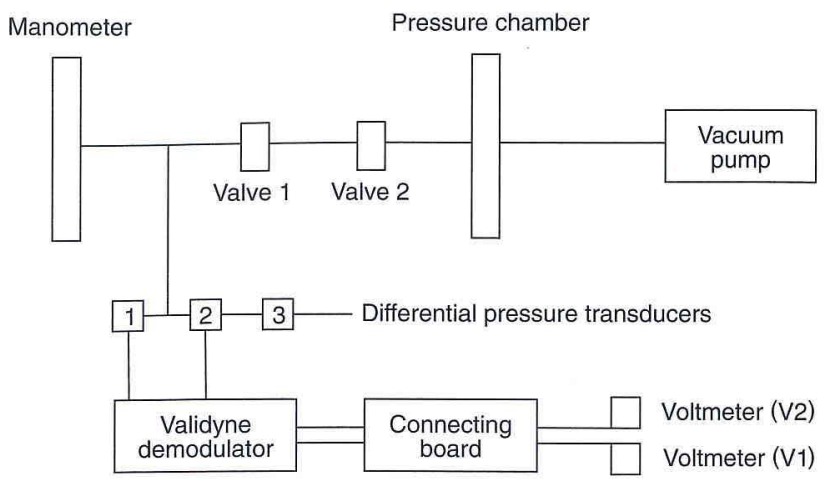

installed in the apparatus as illustrated. Flow-rate through the system was monitored by a flow meter available from Custom Electronics System Inc. (Model 209-SE; Custom. Electronics System; Winston-Salem, NC, U.S.A.). Volumetric flows of $5 \mathrm{ml} / \mathrm{sec}$ to $50 \mathrm{ml} / \mathrm{sec}$ in increments of $5 \mathrm{ml} / \mathrm{sec}$ were imposed by vacuum. Voltage measurements were made for transducers 1 and 2 at each volumetric flow level. Three multi-capillary calibration rods (nominally 114, 154, and $302 \mathrm{~mm} \mathrm{H}_{2} \mathrm{O}$ ) obtained from Tennessee Eastman Company were used to simulate the pressure drop range occurring in a burning cigarette. Voltage readings were acquired for each flow/calibration rod combination.

Equations [3] and [4] were used to calculate $d P$ and $P$ at each flow rate. Subsequently the coefficients in Equation [2] were determined by multiple linear regression analysis of the pressure and flow rate data. The results indicated that the " $\ln (A)$ " and " $B \cdot \ln (P)$ " term in Equation [2] did not contribute significantly to the fit. As a result, Equa-

tion [2] was simplified to:

$\ln (F)=k+C \ln (d P)$.

Substituting for $d P$ gives:

$\ln (F)=k+C \cdot \ln [A+B \cdot V 1]$

or equivalently,

$F=\mathrm{e}^{\mathrm{k}} \cdot[A+B * V 1]^{c}$,

where

$k, A, C$, and $B$

are constant for a given transducer array.

\section{Puff Profile Data Acquisition System}

Measurement of puff profiles with the flow sensor/ transducer system is illustrated in Figure 1. Only the differential pressure, $V 1$, across the flow sensor was required. Digital output of the differential pressure was acquired by the High Speed Recorder option of AsYs-
TANT+ data-acquisition software. The data-acquisition rate was $20.0 \mathrm{~Hz}$ and 100 points per channel were collected.This rate allows readings for five seconds to establish a baseline correction. Data files were stored as an array on the hard disk of an IBM AT computer. Digital output files were converted to voltages by selecting the Convert Data File option in the Data Acquisition Menu page of the AsYSTANT+ software. The software gain was set at 1.0. Digital output conversions were obtained by setting the minimum and maximum voltage output to 0.0 and 5.0, respectively, on the Channel Coefficient Editor page.

Equation [7] was entered into the Functions Option of the Main Menu and coefficients $k, A, C$, and $B$ were entered into Parameters File. Flow-rates were obtained by solving the equation.

The total volume of each 0.4-second segment of a puff was obtained by extracting a subarray of the flow-rate variable and executing the integration option in the Wave and Matrix Operation page of AsYsTANT+. Equation [8] was empirically derived to determine the volume in $\mathrm{cm}^{3}$ for each segment, (vol/segment),

Vol/Segment $=(t / N-1) \cdot V d$,

where

$t$

$N-1$

Vd

is the duration of each segment in seconds,

is the default time scale in seconds, is the integrated volume obtained (by default) in the integration routine.

\section{EXPERIMENT}

Full-flavor (filter) cigarettes were chosen for this study and were conditioned at $60 \%$ relative humidity and $75^{\circ} \mathrm{F}$ $\left(23.89^{\circ} \mathrm{C}\right) *$ for a minimum of 24 hours. Cigarettes were weight selected to fall within one half standard deviation (S.D.) of the mean of 2000 weighed cigarettes (selected weight range $=1003 \mathrm{mg}+/-11.4 \mathrm{mg}$ ). Weight selected cigarettes were then pressure-drop selected to fall within one half S.D. of the mean (pressure-drop selected range $=$ $127.8 \mathrm{~mm} \mathrm{H}_{2} \mathrm{O}+/-3.3 \mathrm{~mm} \mathrm{H}_{2} \mathrm{O}$ at $17.5 \mathrm{~cm}^{3} / \mathrm{sec}$ flowrate).

The displacement volume of the smoking machine's piston was adjusted to obtain a volume of about $70.0 \mathrm{~cm}^{3}$. This adjustment is required to compensate for leaks around the collection pad and produce a smaller puff volume at the cigarette. With the calibrated flow sensor and differential pressure transducers in place, as indicated in Figure 1, a cigarette was loaded into the positivepressure smoking machine. Puff volumes for a lit cigarette were obtained with AsYSTANT+ data acquisition software. Filamatic piston adjustments were made until a total integrated volume of $35.0+/-1 \mathrm{~cm}^{3}$ was achieved. With the flow sensor and cigarette in place, smoking commenced with simultaneous acquisition of puff-profile data, and time-resolved collection of smoke particles within a 2.0-

* Conversion with the Celsius temperature scale is by the formula $\mathrm{F}=2 / 5 \mathrm{C}+32$ 
second puff. The flow-sensor was removed after smoking the first cigarette as indicated in Figure 5. This procedure reduced the dead volume between the butt-end of the cigarette and the collection pad. A total of five cigarettes was smoked to a $28-\mathrm{mm}$ butt length.

The length of the mainstream smoke particulate deposit on the collection pad was $10.0 \mathrm{~cm}$. Each pad was divided into five $2.0-\mathrm{cm}$ segments corresponding to $0.0-0.4$, $0.4-0.8,0.8-1.2,1.2-1.6$, and 1.6-2.0-second time segments during the puff. A specially designed cutter was used to ensure segment precision. The first segment of each collection pad was extracted with a $10.0 \mathrm{ml}$ aliquot of isopropyl alcohol containing $50.0 \mu \mathrm{l}$ of dilute internal standard $(2.0 \mathrm{mg} / \mathrm{ml}$ quinoline $)$. All remaining segments were each extracted in $25.0 \mathrm{ml}$ aliquots of isopropyl alcohol containing $25.0 \mu \mathrm{l}$ of stock internal standard $(1.0 \mathrm{~g} / 100 \mathrm{ml}$ quinoline). All samples were extracted on a wrist action shaker for 20 minutes, then sub-sampled into gas chromatographic sampling vials and analyzed on a gas chromatograph.

A multi-point calibration was obtained using the above working standards. With the appropriate multiplicative normalization factors for sample dilutions, results were obtained directly in $\mu \mathrm{g} /$ time-segment/cigarette.

\section{Figure 5.}

Measurement apparatus for time-resolved yields.

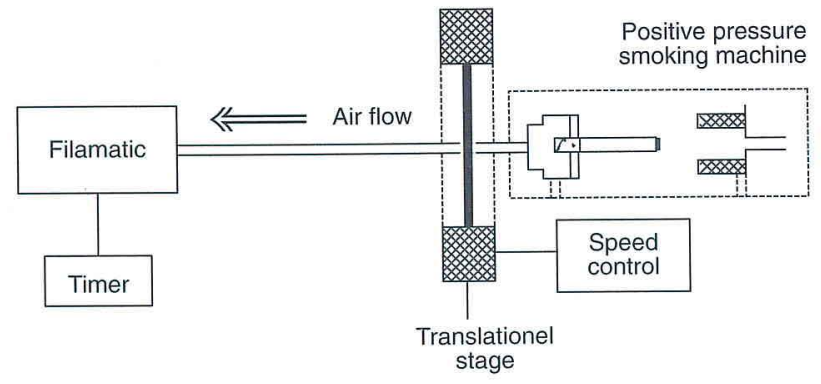

\section{RADIOISOTOPE LABELLING TECHNIQUE}

\section{A. Injection of $\left[2^{\prime}-{ }^{14} \mathrm{C}\right]-$ Nicotine}

$\left[2{ }^{\prime}-{ }^{14} \mathrm{C}\right]$-nicotine (98\% purity; Trademark NEC-689; DuPont; Boston, MA, U.S.A.) was diluted with methanol to achieve a concentration of $12.15 \mu \mathrm{Ci} / \mathrm{ml}$. Selected cigarettes were uniformly injected with $10 \mu \mathrm{l}$ of this solution. They were injected into the center core over a $55-\mathrm{mm}$ range starting at $3 \mathrm{~mm}$ from the filter and ending at $5 \mathrm{~mm}$ from the tobacco end using a $10 \mu \mathrm{l}$ Hamilton syringe with 3-inch capillary needle (Model 701; Reno, NV, U.S.A.).

\section{B. Determination of $\left[2{ }^{\prime}-{ }^{14} \mathrm{C}\right]$-Nicotine Distribution in Cigarette}

Injection homogeneity of $\left[2{ }^{i}-{ }^{14} \mathrm{C}\right]$-nicotine was evaluated. A $\left[2^{\prime}-{ }^{14} \mathrm{C}\right]$-nicotine-labelled cigarette was dissected from the tobacco end into one 11- $\mathrm{mm}$ (representing the lighting puff and first smolder) and nine 6-mm segments. The filter was dissected into two $10-\mathrm{mm}$ segments. The tobacco segments were mixed with cellulose powder to obtain a total sample size not exceeding $1.3 \mathrm{~g}$. These mixtures were oxidized with a Hewlett-Packard Model 306 Oxidizer (United Technologies Packard; Downers Grove, IL, U.S.A.). The resulting $\mathrm{CO}_{2}$ was trapped in a $48 \%$ mixture of Carb-sorb and Permafluor (United Technologies Packard; Downers Grove, IL, U.S.A.). The two filter segments were extracted with $10 \mathrm{ml}$ methanol. A 2-ml aliquot of the resulting extract was then mixed with Scinti-Verse II. All resulting solutions were radioassayed with a Beckman Scintillation Counter LS 7800 (Beckman Instruments, Inc.; Norcross, GA, U.S.A.). Table 19 represents an average distribution of $\left[2^{\prime}-{ }^{14} \mathrm{C}\right]-$ nicotine in three cigarettes.

\section{Smoking and Nicotine Fixation}

$\left[2^{\prime}-{ }^{14} \mathrm{C}\right]$-nicotine-labelled cigarettes were smoked on the IPSA system with simultaneous collection of smoke particles and puff-profile measurements. Due to the gradual loss of $\left[2{ }^{\prime}-{ }^{14} \mathrm{C}\right]$-nicotine activity from the filter pad over time, a preventive fixation technique was applied. Filter pads with smoke particles were mounted on an aluminum sheet $(31 \mathrm{~cm} \times 17 \mathrm{~cm})$, sprayed with a $0.1 \%$ solution of oxalic acid, and dried. Due to the detection limit of most analytical instruments on low concentration of cold nicotine, $\left[2^{\prime}-{ }^{14} \mathrm{C}\right]$-nicotine was chosen for this study.

\section{Radioactivity Scanning of Filter Pads}

Solvent-free filter pads were scanned for total radioactivity with a Berthold Linear Analyzer (Model LB285; Berthold Analytical Instruments; Nashua, NH, U.S.A; equipped with IBM AT computer and LB2821 detector). The intrapuff radioactivity profiles obtained were divided into 0.4-second time segments using the Chroma software (Version 2.0; Berthold Analytical Instruments; Nashua, NH, U.S.A.) supplied with the analyzer. Results are presented in Tables 10-18.

\section{RESULTS}

Intrapuff nicotine distributions obtained from the IPSA system are presented in Tables 2-9. Each nicotine concentration data point represents the average of five experiments with five cigarettes per experiment. Time segments 2,3 , and 4 all fell within 1.16 standard deviations of the mean. Concentration measurements for time segments 1 and 5 (for all puffs) fell within 1.8 standard deviations of the mean. The higher standard error observed in time segments 1 and 5 can be explained by lower nicotine mass and integrated volume. Figures $6 \mathrm{a}$ to $8 \mathrm{a}$ represent measur- 
Table 1.

Chromatographic analysis.

\begin{tabular}{|c|c|}
\hline Gas chromatograph: & Hewlett-Packard 5880 with autosampler \\
\hline Detector: & FID \\
\hline Column: & $\begin{array}{l}\text { DB Wax fused silica } 30 \mathrm{~m} \\
0.32 \mathrm{~mm} \text { ID, film thickness } 0.25 \mu \mathrm{m}\end{array}$ \\
\hline Temperatures: & $\begin{array}{l}\text { Injector } 260^{\circ} \mathrm{C} \\
\text { Detector } 300^{\circ} \mathrm{C} \\
\text { Oven } 125^{\circ} \mathrm{C} \text { to } 210^{\circ} \mathrm{C} \\
\text { program } 1^{\circ} \mathrm{C} / \mathrm{min} \text {. }\end{array}$ \\
\hline Carrier gas: & $\mathrm{He} 1.0 \mathrm{ml} / \mathrm{min}$ \\
\hline Internal standard: & $\begin{array}{l}\text { Quinoline } \\
\text { Stock concentration } 1.0 \mathrm{~g} / 100 \mathrm{ml} \\
\text { Dilute concentration } 2.0 \mathrm{mg} / \mathrm{ml}\end{array}$ \\
\hline Calibration standard: & $\begin{array}{l}\text { Nicotine stock } 0.1 \mathrm{~g} / 100 \mathrm{ml} \\
\text { Worki } \mu \mathrm{g} \text { standards of } 50,100,300,500, \\
1000 \text {, and } 2000 \mu \mathrm{g} \text { were prepared from } \\
\text { the stock. }\end{array}$ \\
\hline
\end{tabular}

Table 2.

Real-time nicotine yield: puff 1 .

\begin{tabular}{c|c|c|c|c}
\hline $\begin{array}{c}\text { Time } \\
(\mathrm{sec})\end{array}$ & $\begin{array}{c}\text { Nicotine mass } \\
\text { concentration } \\
(\mu \mathrm{g} / \mathrm{cig})\end{array}$ & $\begin{array}{c}\text { Integrated } \\
\text { volume } \\
\left(\mathrm{cm}^{3}\right)\end{array}$ & $\begin{array}{c}\text { Nicotine } \\
\text { concentration } \\
\left(\mu \mathrm{g} / \mathrm{cm}^{3}\right)\end{array}$ & \% Yield \\
\hline 0.4 & 0.22 & 2.85 & 0.08 & 0.31 \\
0.8 & 12.49 & 9.11 & 1.37 & 17.23 \\
1.2 & 29.49 & 10.88 & 2.71 & 40.69 \\
1.6 & 22.69 & 8.72 & 2.61 & 31.31 \\
2.0 & 7.58 & 3.96 & 1.93 & 10.46 \\
& $\overline{72.46}$ & $\overline{35.52}$ & $\overline{8.70}$ & \\
\hline
\end{tabular}

Table 3.

Real-time nicotine yield: puff 2 .

\begin{tabular}{c|c|c|c|r}
\hline $\begin{array}{c}\text { Time } \\
(\mathrm{sec})\end{array}$ & $\begin{array}{c}\text { Nicotine mass } \\
\text { concentration } \\
(\mu \mathrm{g} / \mathrm{cig})\end{array}$ & $\begin{array}{c}\text { Integrated } \\
\text { volume } \\
\left(\mathrm{cm}^{3}\right)\end{array}$ & $\begin{array}{c}\text { Nicotine } \\
\text { concentration } \\
\left(\mu \mathrm{g} / \mathrm{cm}^{3}\right)\end{array}$ & $\%$ Yield \\
\hline 0.4 & 0.32 & 3.02 & 0.11 & 0.33 \\
0.8 & 21.00 & 8.93 & 2.36 & 21.48 \\
1.2 & 39.55 & 10.26 & 3.86 & 40.45 \\
1.6 & 28.78 & 8.14 & 3.54 & 29.44 \\
2.0 & 8.11 & 3.38 & 2.42 & 8.30 \\
& $\overline{37.77}$ & $\overline{33.73}$ & $\overline{12.29}$ & \\
\hline
\end{tabular}

Table 4.

Real-time nicotine yield: puff 3 .

\begin{tabular}{c|c|c|c|c}
\hline $\begin{array}{c}\text { Time } \\
(\mathrm{sec})\end{array}$ & $\begin{array}{c}\text { Nicotine mass } \\
\text { concentration } \\
(\mu \mathrm{g} / \mathrm{cig})\end{array}$ & $\begin{array}{c}\text { Integrated } \\
\text { volume } \\
\left(\mathrm{cm}^{3}\right)\end{array}$ & $\begin{array}{c}\text { Nicotine } \\
\text { concentration } \\
\left(\mu \mathrm{g} / \mathrm{cm}^{3}\right)\end{array}$ & $\%$ Yield \\
\hline 0.4 & 0.52 & 3.03 & 0.18 & 0.50 \\
0.8 & 22.56 & 9.08 & 2.49 & 21.46 \\
1.2 & 41.86 & 10.17 & 4.12 & 39.83 \\
1.6 & 31.29 & 8.09 & 3.87 & 29.77 \\
2.0 & 8.88 & 3.17 & 2.81 & 8.45 \\
& & & & \\
Total & 105.11 & $\overline{33.54}$ & $\overline{13.46}$ & \\
\hline
\end{tabular}

Table 5.

Real-time nicotine yield: puff 4.

\begin{tabular}{c|c|c|c|r}
\hline $\begin{array}{c}\text { Time } \\
(\mathrm{sec})\end{array}$ & $\begin{array}{c}\text { Nicotine mass } \\
\text { concentration } \\
(\mu \mathrm{g} / \mathrm{cig})\end{array}$ & $\begin{array}{c}\text { Integrated } \\
\text { volume } \\
\left(\mathrm{cm}^{3}\right)\end{array}$ & $\begin{array}{c}\text { Nicotine } \\
\text { concentration } \\
\left(\mu \mathrm{g} / \mathrm{cm}^{3}\right)\end{array}$ & \% Yield \\
\hline 0.4 & 0.65 & 2.82 & 0.25 & 0.58 \\
0.8 & 28.82 & 8.91 & 3.25 & 25.52 \\
1.2 & 43.33 & 10.36 & 4.19 & 38.36 \\
1.6 & 31.35 & 8.25 & 3.81 & 27.75 \\
2.0 & 8.81 & 3.55 & 2.50 & 7.80 \\
& & & & \\
Total & $\overline{112.96}$ & $\overline{33.88}$ & $\overline{13.99}$ & \\
\hline
\end{tabular}

Table 6.

Real-time nicotine yield: puff 5 .

\begin{tabular}{c|c|c|c|r}
\hline $\begin{array}{c}\text { Time } \\
(\mathrm{sec})\end{array}$ & $\begin{array}{c}\text { Nicotine mass } \\
\text { concentration } \\
(\mu / \mathrm{cig})\end{array}$ & $\begin{array}{c}\text { Integrated } \\
\text { volume } \\
\left(\mathrm{cm}^{3}\right)\end{array}$ & $\begin{array}{c}\text { Nicotine } \\
\text { concentration } \\
\left(\mu / \mathrm{cm}^{3}\right)\end{array}$ & $\%$ Yield \\
\hline 0.4 & 0.79 & 2.95 & 0.29 & 0.66 \\
0.8 & 30.83 & 8.98 & 3.45 & 25.85 \\
1.2 & 45.89 & 10.56 & 4.34 & 38.48 \\
1.6 & 31.56 & 8.23 & 3.83 & 26.47 \\
2.0 & 10.18 & 3.66 & 2.80 & 8.54 \\
& $\overline{119.25}$ & $\overline{34.37}$ & $\overline{14.72}$ & \\
Total & $\overline{119.25}$ & & & \\
\hline
\end{tabular}

Table 7.

Real-time nicotine yield: puff 6 .

\begin{tabular}{c|c|c|c|c}
\hline $\begin{array}{c}\text { Time } \\
(\mathrm{sec})\end{array}$ & $\begin{array}{c}\text { Nicotine mass } \\
\text { concentration } \\
(\mu \mathrm{g} / \mathrm{cig})\end{array}$ & $\begin{array}{c}\text { Integrated } \\
\text { volume } \\
\left(\mathrm{cm}^{3}\right)\end{array}$ & $\begin{array}{c}\text { Nicotine } \\
\text { concentration } \\
\left(\mu \mathrm{g} / \mathrm{cm}^{3}\right)\end{array}$ & \% Yield \\
\hline 0.4 & 1.20 & 2.84 & 0.44 & 0.96 \\
0.8 & 34.65 & 8.79 & 3.96 & 27.71 \\
1.2 & 45.98 & 10.30 & 4.47 & 36.77 \\
1.6 & 32.21 & 8.42 & 3.84 & 25.76 \\
2.0 & 10.99 & 3.81 & 2.89 & 8.79 \\
Total & 125.04 & $\overline{34.15}$ & $\overline{15.59}$ & \\
\hline
\end{tabular}

Table 8.

Real-time nicotine yield: puff 7 .

\begin{tabular}{c|c|c|c|c}
\hline $\begin{array}{c}\text { Time } \\
(\mathrm{sec})\end{array}$ & $\begin{array}{c}\text { Nicotine mass } \\
\text { concentration } \\
(\mu \mathrm{g} / \mathrm{cig})\end{array}$ & $\begin{array}{c}\text { Integrated } \\
\text { volume } \\
\left(\mathrm{cm}^{3}\right)\end{array}$ & $\begin{array}{c}\text { Nicotine } \\
\text { concentration } \\
\left(\mu \mathrm{g} / \mathrm{cm}^{3}\right)\end{array}$ & \% Yield \\
\hline 0.4 & 1.46 & 2.83 & 0.54 & 1.06 \\
0.8 & 36.62 & 8.82 & 4.17 & 26.54 \\
1.2 & 49.74 & 10.31 & 4.83 & 36.05 \\
1.6 & 36.55 & 8.42 & 4.34 & 26.49 \\
2.0 & 13.62 & 3.91 & 3.48 & 9.87 \\
Total & 137.98 & $\overline{34.29}$ & $\overline{17.36}$ & \\
\hline
\end{tabular}


Figure 6a.

Puff 2 flow rate profile.

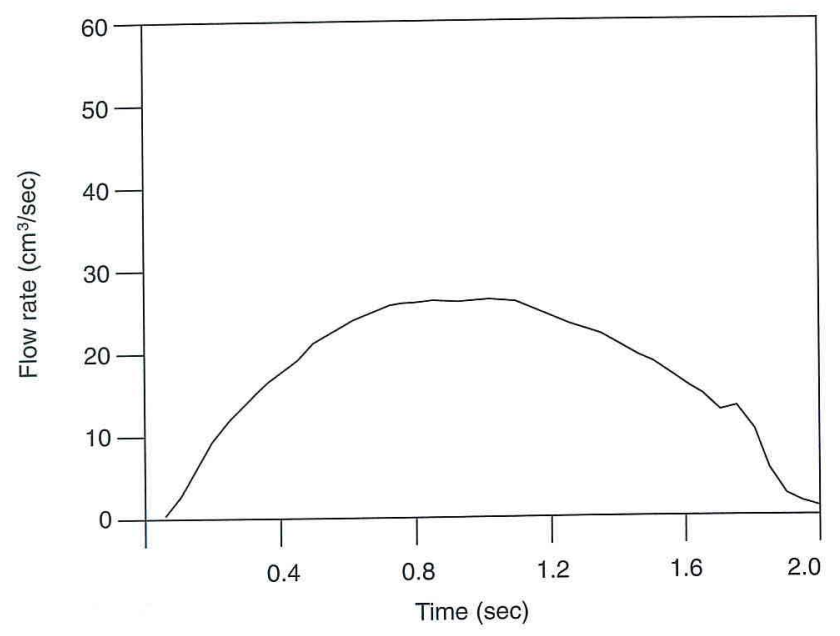

Figure 6b.

Puff 2 nicotine mass profile.

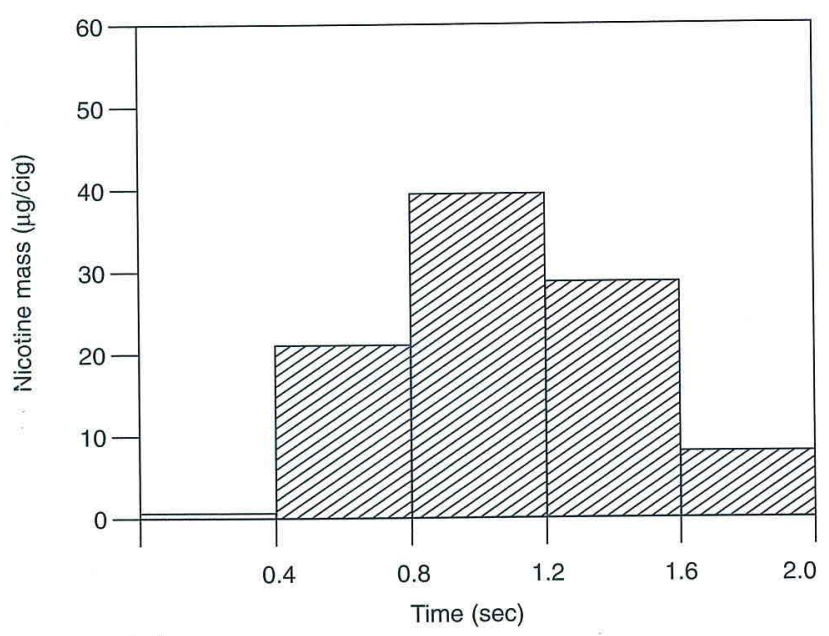

Figure 6c.

Puff 2 nicotine concentration profile.

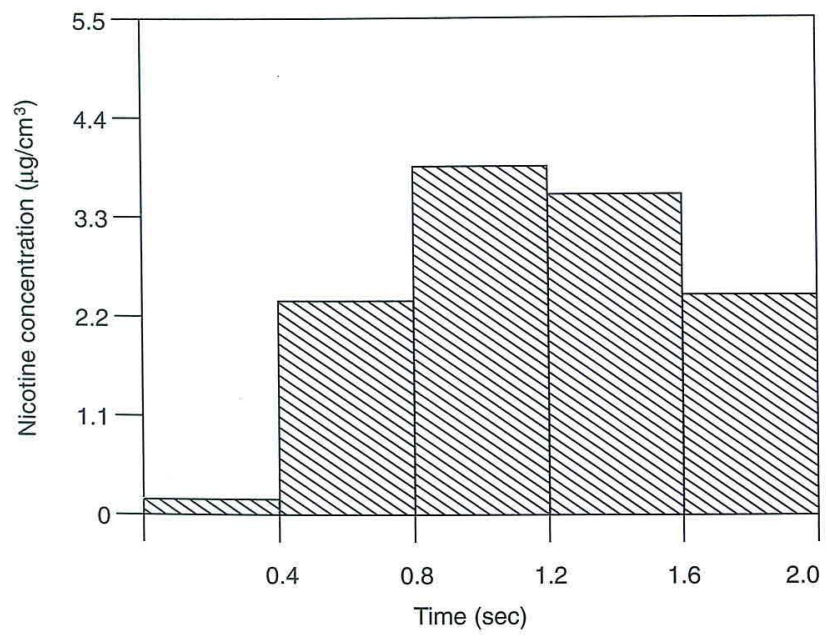

Figure 7a.

Puff 5 flow rate profile.

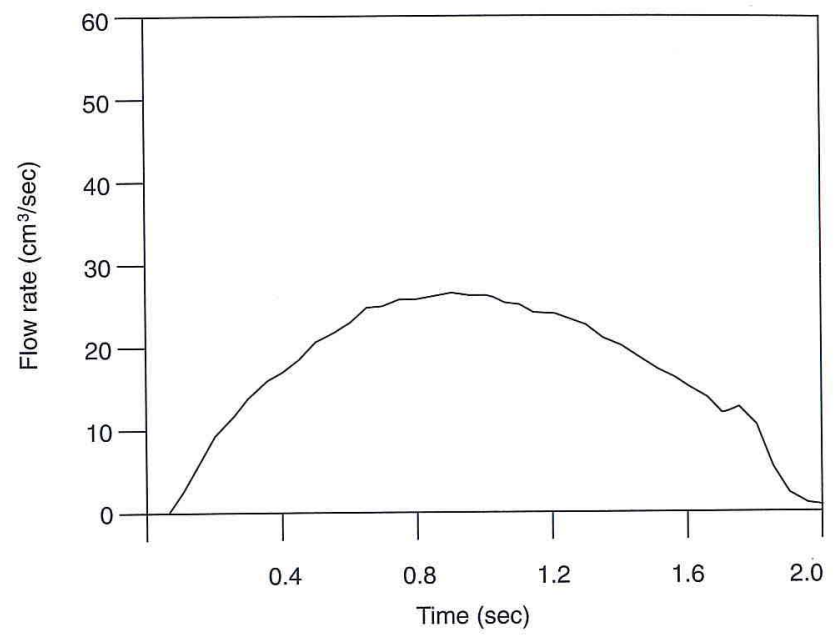

Figure 7b.

Puff 5 nicotine mass profile.

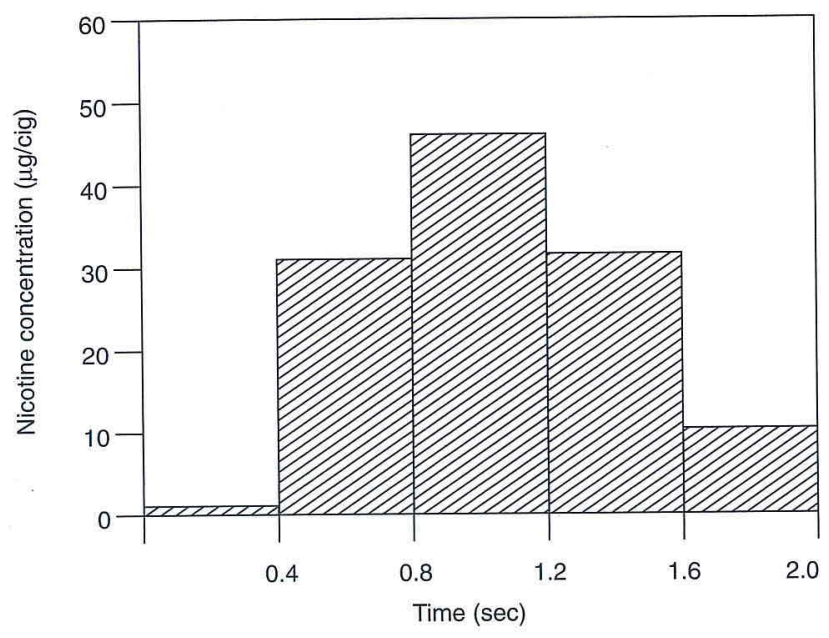

Figure 7c.

Puff 5 nicotine concentration profile.

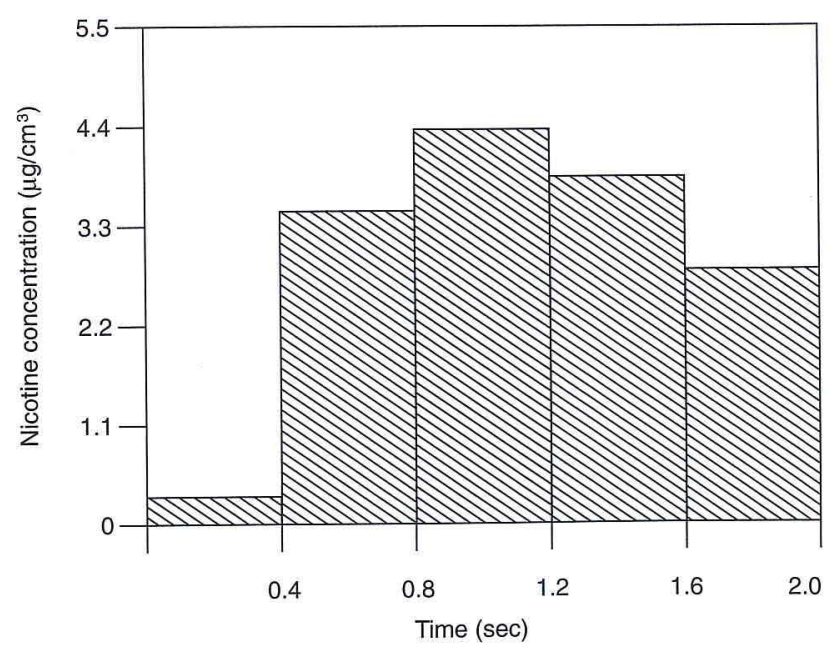


Figure 8a.

Puff 7 flow rate profile.

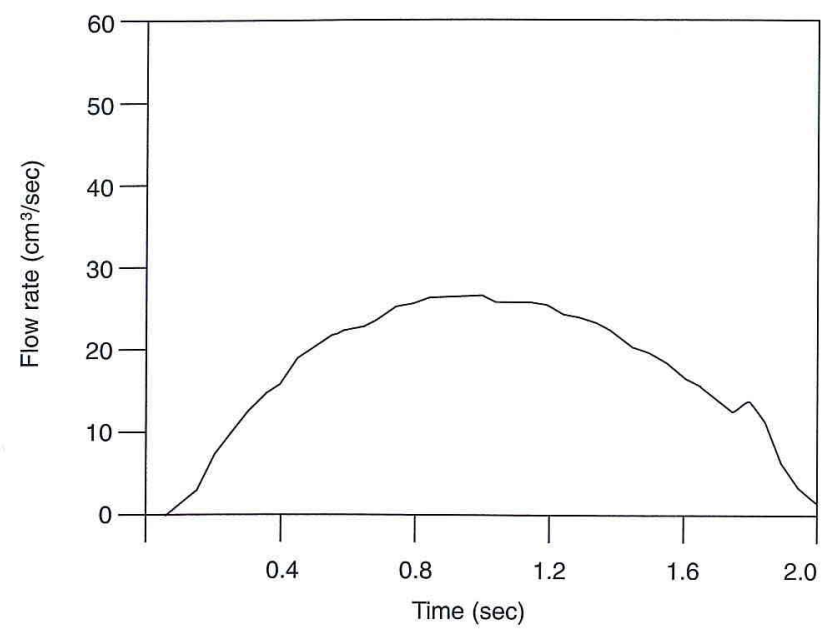

Figure 8b.

Puff 7 nicotine mass profile.

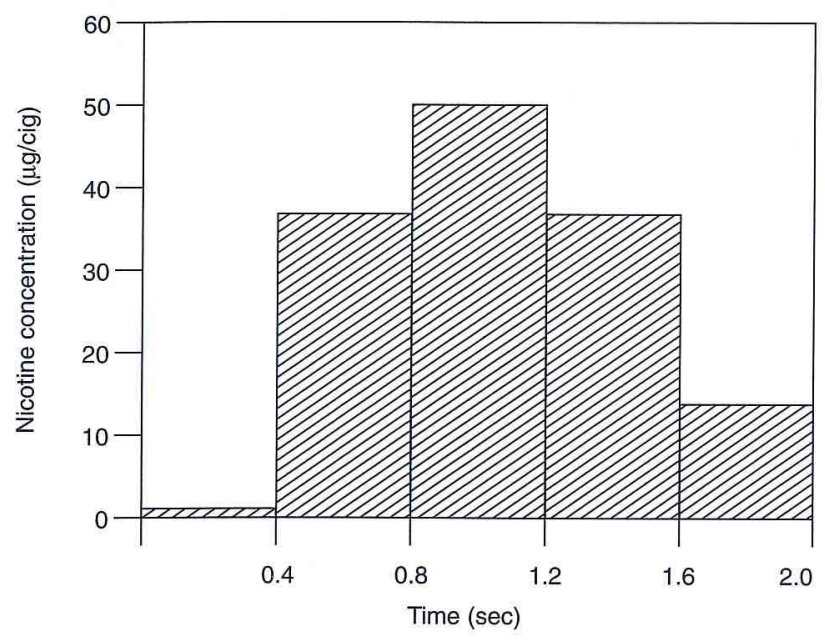

Figure 8c.

Puff 7 nicotine concentration profile.

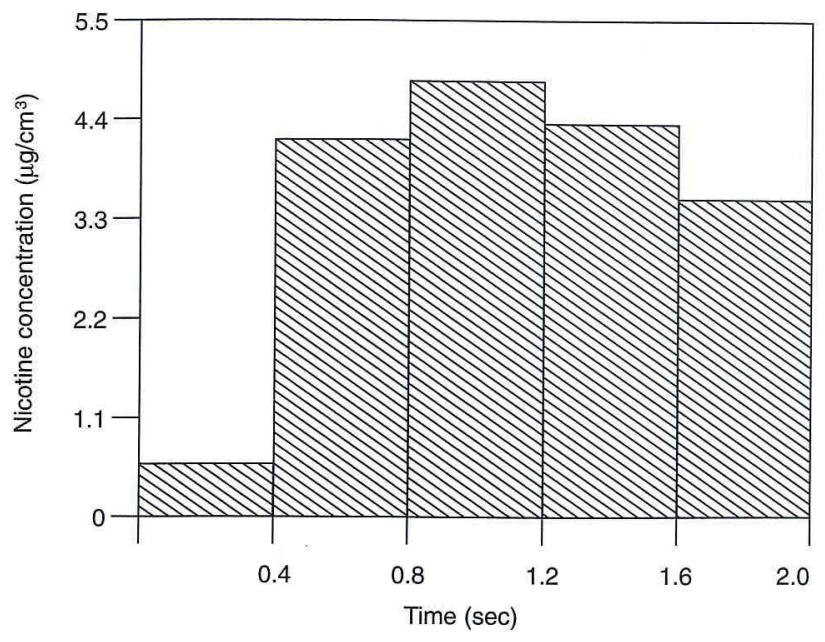

Table 9.

Real-time nicotine yield: puff 8.

\begin{tabular}{c|c|c|c|c}
\hline $\begin{array}{c}\text { Time } \\
(\mathrm{sec})\end{array}$ & $\begin{array}{c}\text { Nicotine mass } \\
\text { concentration } \\
(\mu \mathrm{g} / \mathrm{cig})\end{array}$ & $\begin{array}{c}\text { Integrated } \\
\text { volume } \\
\left(\mathrm{cm}^{3}\right)\end{array}$ & $\begin{array}{c}\text { Nicotine } \\
\text { concentration } \\
\left(\mu \mathrm{g} / \mathrm{cm}^{3}\right)\end{array}$ & $\%$ Yield \\
\hline 0.4 & 1.83 & 3.10 & 0.60 & 1.23 \\
0.8 & 39.40 & 8.81 & 4.48 & 26.34 \\
1.2 & 54.12 & 10.11 & 5.35 & 36.18 \\
1.6 & 39.20 & 8.21 & 4.77 & 26.20 \\
2.0 & 15.06 & 3.85 & 3.92 & 10.06 \\
& & & & \\
Total & $\overline{149.61}$ & $\mathbf{3 4 . 0 8}$ & $\overline{19.12}$ & \\
\hline
\end{tabular}

ed puff profiles for puffs 2, 5, and 7. The profiles exhibited consistent behavior from puff to puff. Integrated volumes were obtained for each 0.4-second time segment under the puff profile measured. Nicotine mass per 0.4-second time segment was obtained directly from gas chromatography on a per-cigarette basis. Figures $6 \mathrm{~b}$ to $8 \mathrm{~b}$ illustrate the distribution of nicotine mass during a 2.0-second puff. Nicotine concentrations $\left(\mu \mathrm{g} / \mathrm{cm}^{3}\right)$ were calculated from mass delivered and corresponding integrated volume. Figures $6 \mathrm{c}$ to $8 \mathrm{c}$ illustrate nicotine concentration profiles for puffs 2, 5 and 7. It is evident from the mass distribution data that the second time segment (0.4-0.8 seconds) exhibits approximately $30 \%$ lower nicotine concentration than the fourth time segment (1.2-1.6 seconds) for puffs 1 to 3 . This suggests that during the first half of these puffs the tobacco rod and filter are more efficient in removing mainstream particles. However, as the puffs progress, removal efficiency is reduced resulting in an increase of nicotine yield. Intrapuff yield for the second and fourth time segments are consistent for puffs 4 to 8 . As illustrated, the nicotine intrapuff distribution is weighted towards the end of the puff. Tables 10-18 represent intrapuff yield of $\left[2^{\prime}-{ }^{14} \mathrm{C}\right]$-nicotine cigarettes.

Table 10.

Real-time $\left[2{ }^{\prime}-{ }^{14} \mathrm{C}\right]$-nicotine yield: puff 1 .

\begin{tabular}{|c|c|c|c|c|}
\hline $\begin{array}{l}\text { Time } \\
(\mathrm{sec})\end{array}$ & $\begin{array}{c}{\left[2{ }^{\prime}-{ }^{14} \mathrm{C}\right]-\text { nico- }} \\
\text { tine activity } \\
(\mathrm{dpm})^{*}\end{array}$ & $\begin{array}{l}\text { Integrated } \\
\text { volume } \\
\left(\mathrm{cm}^{3}\right)\end{array}$ & $\begin{array}{c}{\left[2{ }^{\prime}-{ }^{14} \mathrm{C}\right]-\text { nico- }} \\
\text { tine activity } \\
\left(\mathrm{dpm} / \mathrm{cm}^{3}\right)\end{array}$ & $\%$ Yield \\
\hline 0.4 & 10.47 & 3.76 & 2.79 & 0.28 \\
\hline 0.8 & 398.09 & 9.30 & 42.81 & 10.51 \\
\hline 1.2 & 1698.69 & 10.25 & 165.73 & 44.85 \\
\hline 1.6 & 1447.96 & 8.18 & 177.06 & 38.23 \\
\hline 2.0 & 232.56 & 3.55 & 65.50 & 6.14 \\
\hline Total & 3787.77 & $\overline{35.04}$ & $\overline{453.89}$ & \\
\hline
\end{tabular}


Table 11.

Real-time $\left[2{ }^{\prime}-{ }^{14} \mathrm{C}\right]-$ nicotine yield: puff 2.

\begin{tabular}{|c|c|c|c|c|}
\hline $\begin{array}{l}\text { Time } \\
\text { (sec) }\end{array}$ & $\begin{array}{c}{\left[2{ }^{\prime}-{ }^{14} \mathrm{C}\right]-\text { nico- }} \\
\text { tine activity } \\
(\mathrm{dpm})\end{array}$ & $\begin{array}{l}\text { Integrated } \\
\text { volume } \\
\left(\mathrm{cm}^{3}\right)\end{array}$ & $\begin{array}{c}{\left[2{ }^{\prime}-{ }^{14} \mathrm{C}\right]-n i c o-} \\
\text { tine activity } \\
\left(\mathrm{dpm} / \mathrm{cm}^{3}\right)\end{array}$ & $\%$ Yield \\
\hline 0.4 & 29.08 & 4.13 & 7.04 & 0.46 \\
\hline 0.8 & 731.02 & 9.45 & 77.36 & 11.53 \\
\hline 1.2 & 3243.44 & 10.12 & 320.61 & 51.15 \\
\hline 1.6 & 2083.56 & 7.62 & 273.49 & 32.86 \\
\hline 2.0 & 254.17 & 2.99 & 85.03 & 4.01 \\
\hline Total & $\overline{6341.27}$ & $\overline{34.31}$ & $\overline{763.53}$ & \\
\hline
\end{tabular}

Table 12.

Real-time $\left[2{ }^{\prime}-{ }^{14} \mathrm{C}\right]-$ nicotine yield: puff 3 .

\begin{tabular}{|c|c|c|c|c|}
\hline $\begin{array}{l}\text { Time } \\
\text { (sec) }\end{array}$ & $\begin{array}{l}{\left[2^{\prime}-{ }^{14} \mathrm{C}\right]-\text { nico- }} \\
\text { tine activity } \\
(\mathrm{dpm})\end{array}$ & $\begin{array}{l}\text { Integrated } \\
\text { volume } \\
\left(\mathrm{cm}^{3}\right)\end{array}$ & $\begin{array}{c}{\left[2{ }^{\prime}-{ }^{14} \mathrm{C}\right]-n i c o-} \\
\text { tine activity } \\
\left(\mathrm{dpm} / \mathrm{cm}^{3}\right)\end{array}$ & $\%$ Yield \\
\hline 0.4 & 37.35 & 4.01 & 9.14 & 0.46 \\
\hline 0.8 & 935.29 & 9.30 & 100.61 & 11.64 \\
\hline 1.2 & 4298.11 & 10.34 & 415.49 & 53.49 \\
\hline 1.6 & 2481.17 & 7.92 & 313.12 & 30.88 \\
\hline 2.0 & 282.73 & 3.17 & 89.31 & 3.52 \\
\hline Total & $\overline{8034.65}$ & $\overline{34.82}$ & $\overline{927.68}$ & \\
\hline
\end{tabular}

Table 13.

Real-time $\left[2{ }^{\prime}-{ }^{14} \mathrm{C}\right]-$ nicotine yield: puff 4 .

\begin{tabular}{c|c|c|r|r}
\hline $\begin{array}{l}\text { Time } \\
(\mathrm{sec})\end{array}$ & $\begin{array}{c}{\left[2^{\prime}-{ }^{14} \mathrm{C}\right]-n i c o-} \\
\text { tine activity } \\
(\mathrm{dpm})\end{array}$ & $\begin{array}{c}\text { Integrated } \\
\text { volume } \\
\left(\mathrm{cm}^{3}\right)\end{array}$ & $\begin{array}{c}{\left[2^{\prime}-{ }^{14} \mathrm{C}\right]-\text { nico- }} \\
\text { tine activity } \\
\left(\mathrm{dpm} / \mathrm{cm}^{3}\right)\end{array}$ & \% Yield \\
\hline 0.4 & 37.87 & 4.01 & 9.45 & 0.52 \\
0.8 & 1415.70 & 9.40 & 150.62 & 19.31 \\
1.2 & 3578.40 & 10.37 & 345.08 & 48.81 \\
1.6 & 2001.71 & 7.73 & 258.79 & 27.30 \\
2.0 & 297.69 & 3.07 & 96.83 & 4.06 \\
& & & & \\
Total & 7331.37 & $\overline{34.59}$ & $\overline{860.77}$ & \\
\hline
\end{tabular}

Table 14.

Real-time $\left[2{ }^{\prime}-{ }^{14} \mathrm{C}\right]$-nicotine yield: puff 5 .

\begin{tabular}{c|c|c|c|r}
\hline $\begin{array}{c}\text { Time } \\
(\mathrm{sec})\end{array}$ & $\begin{array}{c}{\left[2^{\prime}-{ }^{14} \mathrm{C}\right]-n i c o-} \\
\text { tine activity } \\
(\mathrm{dpm})\end{array}$ & $\begin{array}{c}\text { Integrated } \\
\text { volume } \\
\left(\mathrm{cm}^{3}\right)\end{array}$ & $\begin{array}{c}{\left[2^{\prime}-{ }^{14} \mathrm{C}\right]-n i c o-} \\
\text { tine activity } \\
\left(\mathrm{dpm} / \mathrm{cm}^{3}\right)\end{array}$ & $\%$ Yield \\
\hline 0.4 & 39.04 & 4.23 & 9.23 & 0.47 \\
0.8 & 1598.93 & 9.63 & 166.03 & 19.30 \\
1.2 & 4437.66 & 10.07 & 440.69 & 53.58 \\
1.6 & 1949.57 & 7.72 & 252.48 & 23.54 \\
2.0 & 257.64 & 2.86 & 89.96 & 3.11 \\
& & & & \\
Total & $\mathbf{8 2 8 2 . 8 4}$ & $\overline{34.52}$ & $\overline{958.39}$ & \\
\hline
\end{tabular}

Table 15.

Real-time $\left[2{ }^{\prime}-{ }^{14} \mathrm{C}\right]-$ nicotine yield: puff 6 .

\begin{tabular}{c|c|c|r|r}
\hline $\begin{array}{c}\text { Time } \\
(\mathrm{sec})\end{array}$ & $\begin{array}{c}{\left[2^{\prime}-{ }^{14} \mathrm{C}\right]-n i c o-} \\
\text { tine activity } \\
(\mathrm{dpm})\end{array}$ & $\begin{array}{c}\text { Integrated } \\
\text { volume } \\
\left(\mathrm{cm}^{3}\right)\end{array}$ & $\begin{array}{c}{\left[2^{\prime}-{ }^{14} \mathrm{C}\right]-n i c o-} \\
\text { tine activity } \\
\left(\mathrm{dpm} / \mathrm{cm}^{3}\right)\end{array}$ & $\%$ Yield \\
\hline 0.4 & 35.07 & 3.35 & 10.46 & 0.35 \\
0.8 & 2166.04 & 9.16 & 236.35 & 21.47 \\
1.2 & 4851.84 & 10.26 & 473.05 & 48.10 \\
1.6 & 2712.54 & 8.03 & 337.76 & 26.89 \\
2.0 & 321.66 & 3.53 & 91.14 & 3.19 \\
& & & & \\
Total & $\mathbf{1 0 0 8 7 . 1 5}$ & $\mathbf{3 4 . 3 3}$ & $\overline{1148.76}$ & \\
\hline
\end{tabular}

Table 16.

Real-time $\left[2{ }^{\prime}-{ }^{14} \mathrm{C}\right]-$ nicotine yield: puff 7 .

\begin{tabular}{|c|c|c|c|c|}
\hline $\begin{array}{l}\text { Time } \\
\text { (sec) }\end{array}$ & $\begin{array}{c}{\left[2{ }^{\prime}-{ }^{14} \mathrm{C}\right]-\text { nico- }} \\
\text { tine activity } \\
(\mathrm{dpm})\end{array}$ & $\begin{array}{l}\text { Integrated } \\
\text { volume } \\
\left(\mathrm{cm}^{3}\right)\end{array}$ & $\begin{array}{c}{\left[2{ }^{\prime}-{ }^{14} \mathrm{C}\right]-\text { nico- }} \\
\text { tine activity } \\
\left(\mathrm{dpm} / \mathrm{cm}^{3}\right)\end{array}$ & $\%$ Yield \\
\hline 0.4 & 42.29 & 3.91 & 10.82 & 0.55 \\
\hline 0.8 & 1638.74 & 9.33 & 175.69 & 21.17 \\
\hline 1.2 & 3556.85 & 10.42 & 341.50 & 45.95 \\
\hline 1.6 & 2216.22 & 7.70 & 287.80 & 28.63 \\
\hline 2.0 & 285.77 & 3.54 & 80.74 & 3.69 \\
\hline Total & $\overline{7739.87}$ & $\overline{34.89}$ & $\overline{896.55}$ & \\
\hline
\end{tabular}

Table 17.

Real-time $\left[2{ }^{\prime}-{ }^{14} \mathrm{C}\right]$-nicotine yield: puff 8 .

\begin{tabular}{c|c|c|c|c}
\hline $\begin{array}{c}\text { Time } \\
(\mathrm{sec})\end{array}$ & $\begin{array}{c}{\left[2^{\prime}-{ }^{14} \mathrm{C}\right]-\text { nico- }} \\
\text { tine activity } \\
(\mathrm{dpm})\end{array}$ & $\begin{array}{c}\text { Integrated } \\
\text { volume } \\
\left(\mathrm{cm}^{3}\right)\end{array}$ & $\begin{array}{c}{\left[2^{\prime}-{ }^{14} \mathrm{C}\right]-n i c o-} \\
\text { tine activity } \\
\left(\mathrm{dpm} / \mathrm{cm}^{3}\right)\end{array}$ & $\%$ Yield \\
\hline 0.4 & 38.67 & 3.84 & 10.07 & 0.62 \\
0.8 & 1436.19 & 9.47 & 151.59 & 22.99 \\
1.2 & 2695.31 & 10.14 & 265.69 & 43.15 \\
1.6 & 1801.07 & 7.78 & 231.59 & 28.83 \\
2.0 & 274.90 & 3.72 & 73.81 & 4.40 \\
& & & & \\
Total & 6246.14 & $\overline{34.96}$ & $\overline{732.74}$ & \\
\hline
\end{tabular}

Table 18.

Real-time $\left[2{ }^{\prime}-{ }^{14} \mathrm{C}\right]$-nicotine yield: puff 9.

\begin{tabular}{c|c|c|r|r}
\hline $\begin{array}{c}\text { Time } \\
(\mathrm{sec})\end{array}$ & $\begin{array}{c}{\left[22^{\prime}-{ }^{14} \mathrm{C}\right]-\text { nico- }} \\
\text { tine activity } \\
(\mathrm{dpm})\end{array}$ & $\begin{array}{c}\text { Integrated } \\
\text { volume } \\
\left(\mathrm{cm}^{3}\right)\end{array}$ & $\begin{array}{c}{\left[2^{\prime}-{ }^{14} \mathrm{C}\right]-\text {-nico- }} \\
\text { tine activity } \\
\left(\mathrm{dpm} / \mathrm{cm}^{3}\right)\end{array}$ & $\%$ Yield \\
\hline 0.4 & 41.42 & 4.22 & 9.82 & 0.67 \\
0.8 & 1185.71 & 9.39 & 126.21 & 19.17 \\
1.2 & 2699.17 & 10.20 & 264.61 & 43.64 \\
1.6 & 1981.70 & 7.73 & 256.47 & 32.04 \\
2.0 & 277.23 & 3.52 & 78.73 & 4.48 \\
& & & & \\
Total & 6185.23 & $\overline{35.06}$ & $\overline{735.84}$ & \\
\hline
\end{tabular}


Figure 9a.

Puff 2 flow rate profile.

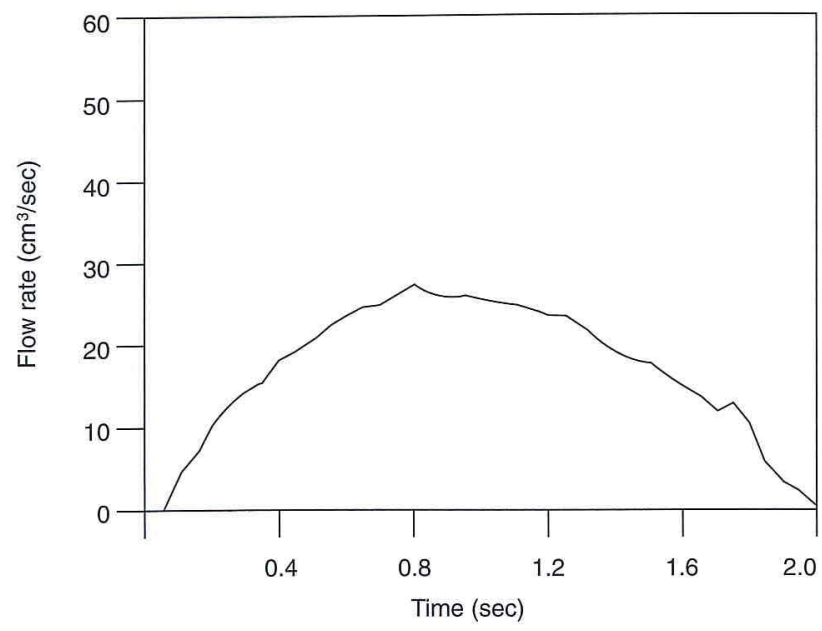

Figure $9 b$.

Puff $2{ }^{14} \mathrm{C}$-nicotine profile.

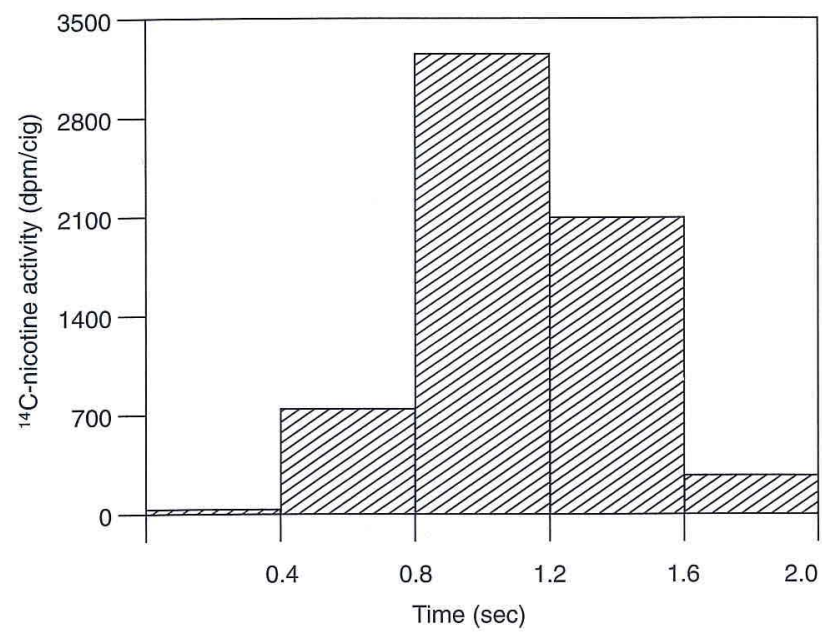

Figure $9 c$.

Puff $2{ }^{14} \mathrm{C}$-nicotine concentration profile.

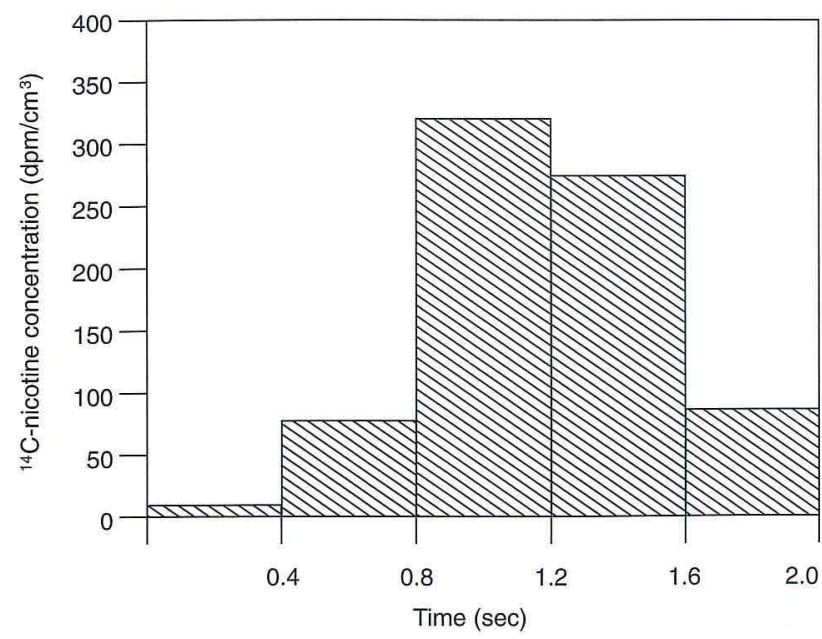

Figure 10a.

Puff 5 flow rate profile.

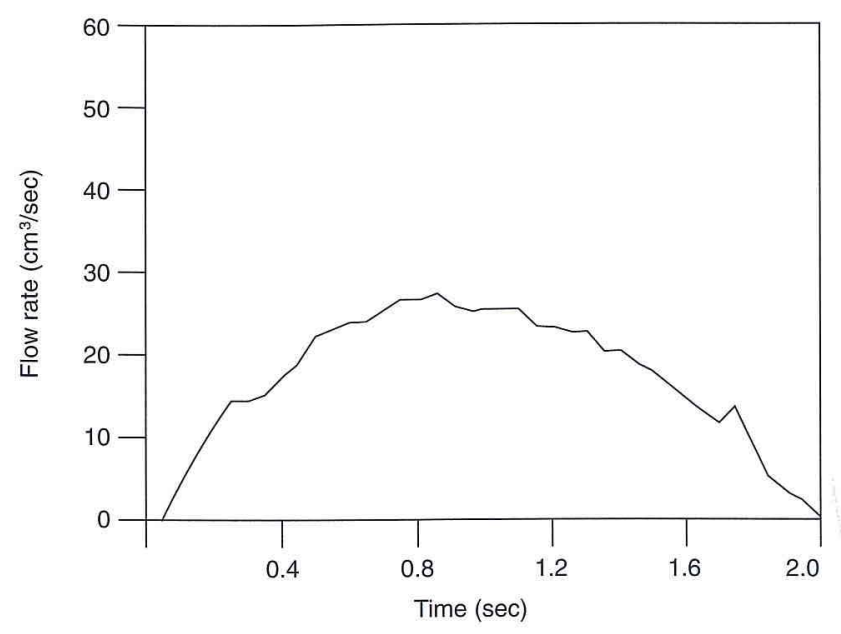

Figure $10 b$.

Puff $5{ }^{14} \mathrm{C}$-nicotine profile.

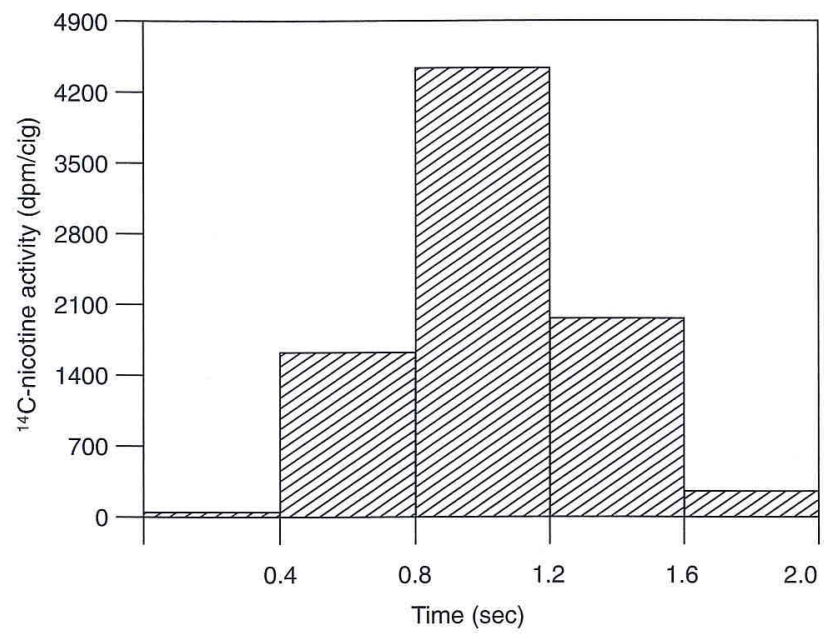

Figure 10c.

Puff $5{ }^{14} \mathrm{C}$-nicotine concentration profile.

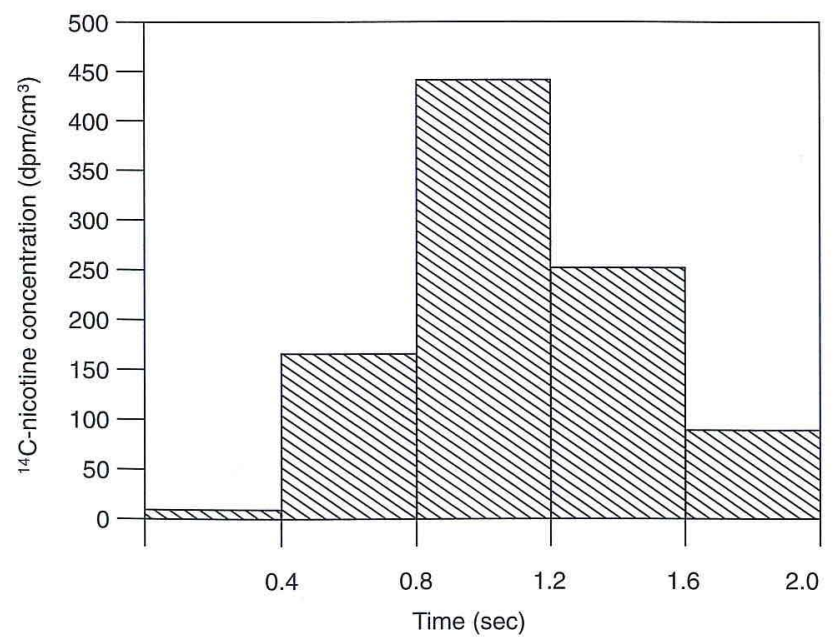


Figure 11a.

Puff 7 flow rate profile.

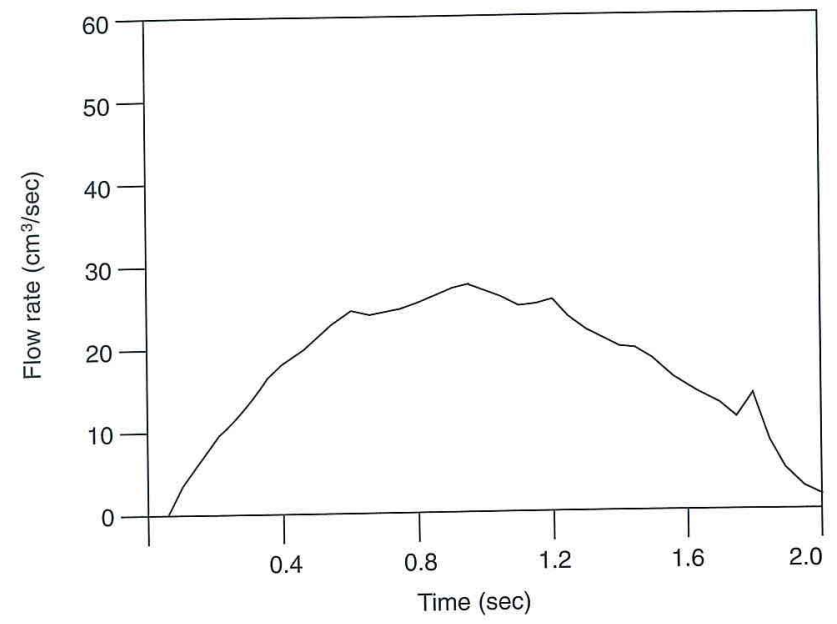

Figure $11 b$.

Puff $7{ }^{14} \mathrm{C}$-nicotine profile.

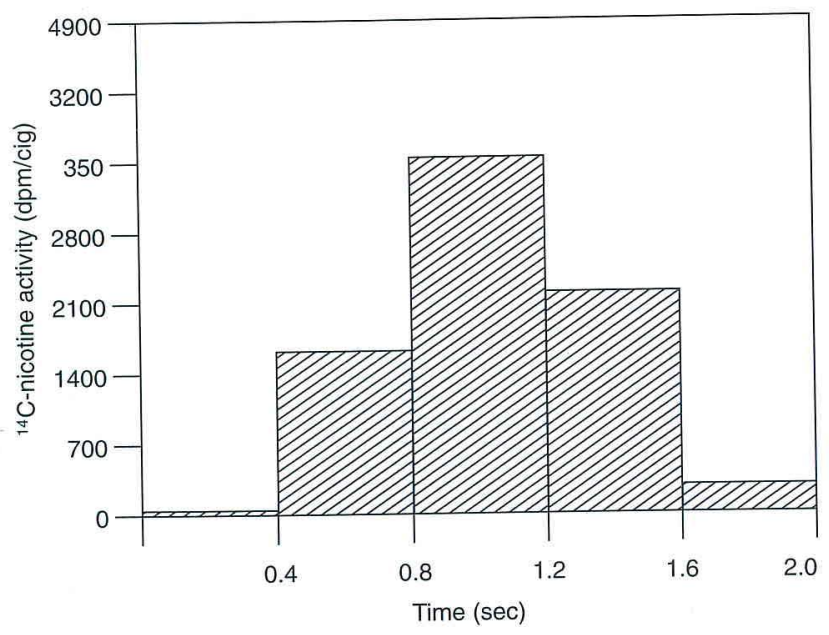

Figure 11c.

Puff $7{ }^{14} \mathrm{C}$-nicotine concentration profile.

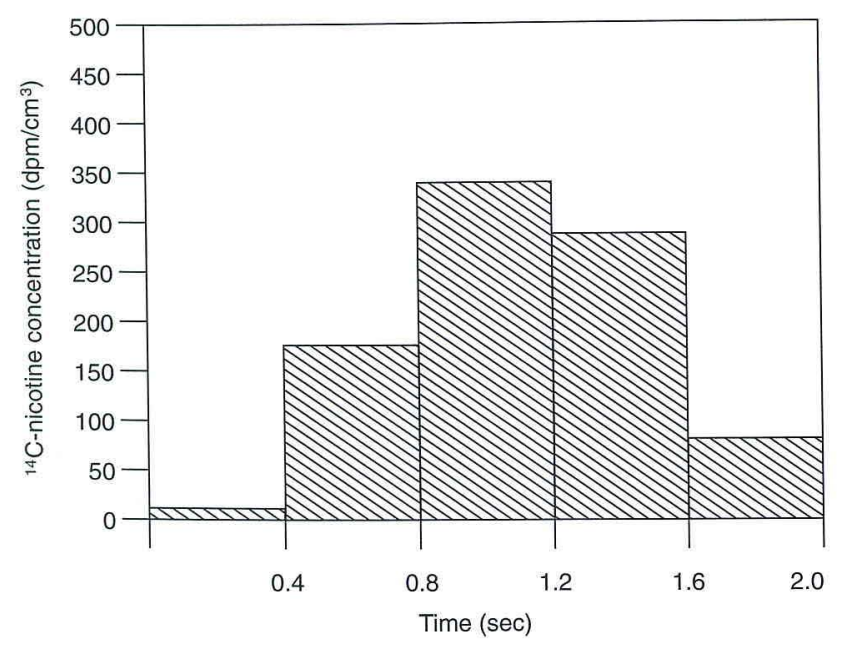

\section{DISCUSSION}

The nicotine concentrations obtained agree well with earlier studies (2) of intrapuff particle concentration. The relatively small amount of particles measured in the first one-half second of the puff are consistent with the low nicotine concentration measured. Similarly, the large mass of particles near the plateau at the middle of the puff correlates with the high nicotine concentration measured. The total nicotine concentration per puff increases from puff-to-puff as nicotine distills and redistills along the tobacco rod. This phenomenon was expected and agrees with puff-by-puff data. However, the delivery of intrinsic cell-bound (endogenous) nicotine cannot be ruled out as a contributor to the increase in nicotine concentration observed (Tables 2 to 9).

Tables 10 to 18 report real-time, $\left[2-{ }^{14} \mathrm{C}\right]$-nicotine intrapuff yields. These results show strong correlation with the chromatographic data, in that $\left[2{ }^{\prime}-{ }^{14} \mathrm{C}\right]$-nicotine yield is weighted to the end of the puff. However, it was observed that the total ${ }^{14} \mathrm{C}$ activity per puff plateaus at puff 6 , and then decreases for puffs 7,8 and 9. This phenomenon is observed in the distribution reported in Table 19, and was attributed to the injection labelling process. Integrated volumes for each 0.4 -second time segment were obtained numerically. The $\left[2{ }^{\prime}-{ }^{14} \mathrm{C}\right]$-nicotine activity/ $\mathrm{cm}^{3}$ was calculated from measured and corresponding volume.

Table 19.

Distribution of $\left[2^{\prime}-{ }^{14} \mathrm{C}\right]$-nicotine in cigarettes.

\begin{tabular}{|c|c|c|c|c|c|c|c|c|c|c|c|}
\hline \multicolumn{6}{|c|}{ Cigarette section } & \multicolumn{6}{|c|}{$\left[2^{\prime}-{ }^{14} \mathrm{C}\right]-$ nicotine activity } \\
\hline \multicolumn{6}{|c|}{$\mathrm{T} 10$} & \multicolumn{6}{|c|}{3535.3} \\
\hline \multicolumn{6}{|c|}{ T9 } & \multicolumn{6}{|c|}{3717.1} \\
\hline \multicolumn{6}{|c|}{ T8 } & \multicolumn{6}{|c|}{3714.2} \\
\hline \multicolumn{6}{|c|}{$\mathrm{T7}$} & \multicolumn{6}{|c|}{3447.5} \\
\hline \multicolumn{6}{|c|}{ T6 } & \multicolumn{6}{|c|}{4074.9} \\
\hline \multicolumn{6}{|c|}{ T5 } & \multicolumn{6}{|c|}{5759.9} \\
\hline \multicolumn{6}{|c|}{$\mathrm{T} 4$} & \multicolumn{6}{|c|}{5597.2} \\
\hline \multicolumn{6}{|c|}{ T3 } & \multicolumn{6}{|c|}{1713.2} \\
\hline \multicolumn{6}{|c|}{ T2 } & \multicolumn{6}{|c|}{1360.4} \\
\hline \multicolumn{6}{|c|}{$\mathrm{T} 1$} & \multicolumn{6}{|c|}{1091.3} \\
\hline \multirow{2}{*}{\multicolumn{6}{|c|}{$\begin{array}{l}\mathrm{F} 2 \\
\mathrm{~F} 1\end{array}$}} & \multicolumn{6}{|c|}{0.0} \\
\hline \multicolumn{4}{|c|}{$\mathrm{F} 1$} & & & \multicolumn{6}{|c|}{0.0} \\
\hline F1 & $\mathrm{F} 2$ & T1 & T2 & T3 & T4 & T5 & T6 & T7 & T8 & T9 & T10 \\
\hline
\end{tabular}

It is evident that the intrapuff nicotine yield is a function of flowrate. However, variables such as coal combustion temperatures cannot be ignored (4). The intrapuff technique presented here provides another method for analysing mainstream smoke in greater detail. 


\section{REFERENCES}

1. Gordon, L. B., A. B. Norman, and J. H. Reynolds: Unpublished results.

2. Ingebrethsen, B. J.: Evolution of the particle size distribution of mainstream smoke during a puff; Aerosol Sci. Technol. 5 (1986) 423-433.

3. Ceschini, P., and A. Lafaye: Evolution of gas-vapour phase and the total particulate matter of cigarette smoke in a single puff; Beitr. Tabakforsch. 8 (1976) 378-381.

4. Baker, R. R.: Temperature variation within a cigarette combustion coal during the smoking cycle; High Temperature Sci. 7 (1975) 236-247.

\section{Acknowledgements}

The assistance of Mr. Scott Simmons, Ms. Cynthia Lyman, Karen Winningham, and Donza Friende as well as consultations with Drs. David Townsend and Stephen Sears are gratefully acknowledged.

Authors' address:

R. J. Reynolds Tobacco Company,

Research and Development,

Bowman Gray Technical Center,

Winston-Salem, North Carolina, 27102, U.S.A. 